\title{
3 Goal programming for financial portfolio management: \\ 4 a state-of-the-art review
}

\author{
5 Cinzia Colapinto $^{1,2}(\mathbb{D}) \cdot$ Davide La Torre $^{3,4} \cdot$ Belaid Aouni $^{5}$
}

6 Received: 14 February 2017/Revised: 29 May 2017/Accepted: 11 July 2017

7 (c) Springer-Verlag GmbH Germany 2017

8 Abstract Over the last decades, the Goal Programming (GP) model has been 9 applied to financial portfolio management and/or selection problem in decision10 making contexts where several conflicting and incommensurable objectives are 11 simultaneously aggregated. The aim of this paper is to identify the research trends 12 and publication outlets for the application of GP model to portfolio management. 13 We point out an increasing interest and affirmation of more sophisticated models. 14 We present a characterization of the existing GP variants and provide historical data 15 and statistical analysis.

16

Keywords Goal programming · Financial portfolio selection · Typology

A7 1 Graduate School of Business, Nazarbayev University, 53 Kabanbay batyr ave., Block C3, A8 Astana 010000, Kazakhstan

A9 2 Department of Management, Ca' Foscari University of Venice, Cannaregio, 873, Fondamenta A10 San Giobbe, 30121 Venice, Italy

A11 3 Department of Mathematics, Nazarbayev University, Astana, Kazakhstan

A12 4 Department of Economics, Management, and Quantitative Methods, University of Milan, A13 Milan, Italy

A14 5 College of Business and Economics, Qatar University, 2713 Doha, Qatar

\begin{tabular}{|c|c|c|c|}
\hline & $\begin{array}{l}\text { Journal : Small-ext 12351 } \\
\text { Article No. : } \quad 337 \\
\text { MS Code : } \\
\text { ORIJ-D-17-00079 }\end{array}$ & $\begin{array}{l}\text { Dispatch : } \mathbf{1 5 - 7 - 2 0 1 7} \\
\square \quad \text { LE } \\
\nabla \quad \mathrm{CP} \\
\square \quad\end{array}$ & $\begin{array}{l}\text { Pages : } \mathbf{2 0} \\
\square \quad \text { TYPESET } \\
\square \quad \text { DISK } \\
\end{array}$ \\
\hline
\end{tabular}




\section{$21 \quad 1$ Introduction}

22 During the last two decades we have noticed a rapid increase of publications using 23 different variants of the Goal Programming (GP) model for portfolio selection (Lin 24 and O'Leary 1993; Aouni 2009, 2010; Azmi and Tamiz 2010; Aouni et al. 2014). 25 The GP model enables the Financial Decision Maker (FDM) to aggregate several 26 financial dimensions in order to select the best compromise portfolio. The FDM can 27 be an investor, a portfolio manager, a financial analyst or a financial councillor. The 28 FDM is requested to choose the appropriate GP variant to deal with a specific 29 portfolio selection situation depending on the nature of the available information within the specific financial decision-making situation and the market performance.

In this paper we focus on portfolio selection and management that involve the construction of a portfolio of securities (such as stocks, bonds, treasury bills and mutual funds), that maximizes the FDM utility and accommodate his/her preferences. The conducted literature review reveals that there are at least one hundred and fifty publications applying the GP model to financial portfolio management. These publications are dealing with decision making situations in which the type of information can be (a) deterministic (ninety-two papers), (b) stochastic (twenty-nine papers), and (c) fuzzy or imprecise (thirty-four articles). The aim of this paper is to review the main theoretical developments and applications of different GP model variants to financial portfolio selection and management.

The paper is structured as follows: Sect. 2 provides a brief review of the most important GP variants that have been developed and applied to portfolio management and points out the advantages of each variant. Section 3, which is the core of the paper, describes how data have been collected and then classified. Section 4 is devoted to the presentation of our analysis and to the discussion of the main results. Finally, Sect. 5 concludes the paper and provides some recommendations for future research.

\section{Goal programming for financial portfolio selection}

50 The bi-criteria financial portfolio selection model was developed by Markowitz 51 in (1952) and published in a fundamental paper published in the Journal of 52 Finance. His model aggregates simultaneously the expected return and the risk 53 of a given portfolio. These two dimensions are incommensurable since both 54 criteria are measured through different scales and units. The security return and 55 risk are also conflicting in a situation where high returns are correlated to high 56 risks and vice versa. The aggregation of both dimensions requires the FDM to 57 provide some tradeoffs (compromises) based on his/her preferences and value 58 system.

59 The mathematical formulation of (Markowitz 1952) model reads as follows:

60 1. Attribute 1: The expected return of the portfolio, $\sum_{j=1}^{n} E_{j} x_{j}$, to be maximized,

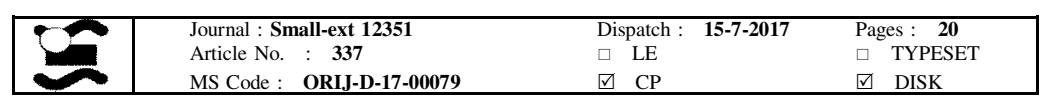


2. Attribute 2: The portfolio risk, $\sum_{j=1}^{n} \sum_{k=1}^{n} x_{j} \sigma_{j k} x_{k}$, to be minimized.

Subject to:

$$
\sum_{\substack{j=1 \\ x \in F,}}^{n} x_{j}=1,
$$

where: $x_{j}$, proportion to be invested in the security $j ; E_{j}$, expected return of security $j ; \sigma_{j k}$, covariance of the returns of securities $j$ and $k ; F$, set of feasible solutions.

The aggregation of both attributes 1 and 2 can be done either by determining the minimum variance portfolio subject to an expected return $E^{*}$ :

$$
\text { Minimize } \sum_{i=1}^{n} \sum_{j=1}^{n} x_{i} \sigma_{i j} x_{j}
$$

70 Subject to:

$$
\sum_{i=1}^{n} E_{i} x_{i}=E^{*}
$$

76 or by maximizing the expected portfolio return subject to a maximum level of sustainable and affordable risk $R^{*}$ :

$$
\text { Maximize } \sum_{i=1}^{n} E_{i} x_{i}
$$

79 Subject to:

$$
\sum_{i=1}^{n} \sum_{j=1}^{n} x_{i} \sigma_{i j} x_{j} \leq R^{*}
$$

$$
\sum_{i=1}^{n} x_{i}=1
$$

\begin{tabular}{|c|c|c|c|}
\hline & $\begin{array}{l}\text { Journal : Small-ext 12351 } \\
\text { Article No. : } \quad 337 \\
\text { MS Code : } \\
\text { ORIJ-D-17-00079 }\end{array}$ & $\begin{array}{l}\text { Dispatch : } \mathbf{1 5 - 7 - 2 0 1 7} \\
\square \quad \text { LE } \\
\nabla \quad \mathrm{CP} \\
\square \quad\end{array}$ & $\begin{array}{l}\text { Pages : } \mathbf{2 0} \\
\square \quad \text { TYPESET } \\
\square \quad \text { DISK } \\
\end{array}$ \\
\hline
\end{tabular}

$$
x \in F .
$$

85 Since the introduction of Markowitz model, several other attempts have been 87 proposed to consider more sophisticated portfolio models able to capture more 88 investment features and improve the overall performance. In fact, empirical 89 evidence demonstrates that in order to select the best financial portfolio it is required 
90 to aggregate more than two dimensions. The FDM may want to optimize 91 simultaneously several incommensurable and conflicting attributes such as:

92 (a) return rate; (b) risk; (c) liquidity; (d) gross book value per share; (e) capitalization 93 ratio; and (f) stock market value of each company. Zopounidis et al. (1999) 94 identified fifteen criteria and they grouped them into the following three categories: 95 corporate validity; acceptability of stocks by the investors, and financial vigor. 9 $\mathbf{A Q 2}$ Within each category, five attributes have been listed (see Table 1).

97 As presented in the above Table 1, solving a portfolio selection problem requires 98 partial or total attribute aggregation. The GP model is one of the aggregation 99 procedures that has been widely utilized in portfolio management. Its methodolog100 ical framework is based on the Distance Function (DF) model. In general the DF 101 model aims at minimizing the following quantity

$$
\sum_{i=1}^{p}\left[w_{i}\left|g_{i}-f_{i}(x)\right|^{r}\right]^{1 / r}
$$

103 that expresses the weighted sum of the Euclidean distance between $g_{i}$ and $f_{i}(x)$ for 104 any $x$ belonging to the feasible set $F$. The coefficients $w_{i}$ represent the relative 105 importance of each objective $f_{i}(x)$ and $r$ defines the family type of the Euclidean 106 distance functions. The absolute deviation $\left|g_{i}-f_{i}(x)\right|$ measures the distance between 107 the achievement levels $f_{i}(x)$ and the aspiration levels (goals) $g_{i}$. The linear formu108 lation of the DF model, known as Goal Programming model, was introduced by 109 Charnes et al. (1955) and Charnes and Cooper (1961). Their formulations are 110 characterized by the presence of positive and negative deviations, both to be

Table 1 Different dimensions for portfolio selection

\begin{tabular}{ll}
\hline Category & Attributes \\
\hline Corporate validity criteria & Gross book value per share \\
Capitalization ratio \\
Stock market value of each firm \\
Acceptability of stocks by the investors & The marketability of each share \\
& Financial position progress \\
Financial vigor criteria & Dividend yield \\
& Capital gain \\
& Exchange flow ratio \\
& Round lots traded per day \\
& Transaction value per day \\
& Equity ratio \\
\hline & Price/earnings ratio \\
& Structure ratio \\
& Equity/debt ratio \\
\end{tabular}

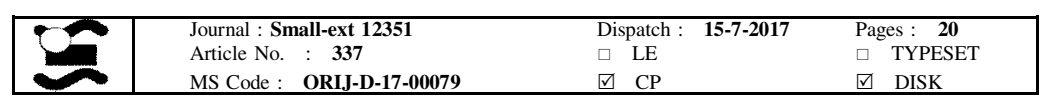


minimized: both underachievement and overachievement of objectives are unwanted according to the satisfying philosophy. In other words, the decision maker will penalize both positive and negative deviations.

The standard formulation of the GP introduced by Charnes and Cooper (1961) reads as follows:

$$
\operatorname{Min} \sum_{i=1}^{n}\left(\delta_{i}^{-}+\delta_{i}^{+}\right)
$$

Subject to:

$$
f_{i}(x)+\delta_{i}^{-}-\delta_{i}^{+}=g_{i}(i=1,2, \ldots, p)
$$

$$
x \in F
$$

$$
\delta_{i}^{-}, \delta_{i}^{+} \geq 0(i=1,2, \ldots, p)
$$

where $\delta_{i}^{-}$and $\delta_{j}^{-}$are the negative and positive deviations, respectively. Since the objectives are conflicting, the obtained solution can be qualified as the solution of the best compromise or the most satisfactory solution. According to Martel and Aouni (1990) and Aouni et al. (2009), the GP model is simpler and easier to understand and to apply than other Multiple Criteria Decision Aid (MCDA) and/or Multiple Objective Programming (MOP) techniques. GP models can easily be implemented by using some powerful commercial software such as AMPL, Lingo, and CPLEX. The large number of its applications in several domains including portfolio selection demonstrates its potential and shows its applicability and effectiveness in practice. Furthermore, in Aouni et al. (2009) the authors showed that the GP model allows an explicit integration of the DM preferences and it requires limited information during the process of preference elucidation with respect to other models used within the MOP paradigm.

For more than 60 years, the GP model has become the most popular model in MCDA and MOP and widely implemented in financial portfolio management (Aouni et al. 2014). Indeed, different GP variants have been applied and they range from Weighted Goal Programming (WGP) to Lexicographic Goal programming (LGP), from Polynomial Goal Programming (PGP) to Stochastic Goal Programming (SGP), and finally to Fuzzy Goal Programming (FGP). The GP variants were applied according to the nature of the decision-making situation and the available information about the objective functions, decision variables and decision-making parameters (Azmi and Tamiz 2010; Aouni et al. 2014).

Through the WGP, the FDM may express his/her preferences by assigning weights to positive and negative deviations. Pendaraki et al. (2005); Bilbao-Terol et al. (2015) and Bravo et al. (2010) have utilized the WGP for financial portfolio selection where the relative importance of both risk and return objectives were expressed through the weights $w_{i}^{+}$and $w_{i}^{-}$associated with positive and negative deviations, respectively. In fact the weights have a double role, namely:

\begin{tabular}{|c|c|c|c|}
\hline & $\begin{array}{l}\text { Journal : Small-ext 12351 } \\
\text { Article No. : } \quad 337 \\
\text { MS Code : } \\
\text { ORIJ-D-17-00079 }\end{array}$ & $\begin{array}{l}\text { Dispatch : } \mathbf{1 5 - 7 - 2 0 1 7} \\
\square \quad \text { LE } \\
\nabla \quad \mathrm{CP} \\
\square \quad\end{array}$ & $\begin{array}{l}\text { Pages : } \mathbf{2 0} \\
\square \quad \text { TYPESET } \\
\square \quad \text { DISK } \\
\end{array}$ \\
\hline
\end{tabular}
(a) standardization of the units and scales of measurement and (b) valorization of the Decision-Maker's preferences (Kettani et al. 2004). 
The LGP, also known as pre-emptive GP, allows the FDM to rank the objectives according to a lexicographic order based on their relative importance. The deviations of a higher level of priority are introduced as constraints within the subsequent mathematical programs related to the objectives of lower levels of priority. As a result, the objectives in the lower priority levels play a marginal role in the decision-making process. Lee (1972) has developed the first formulation of LGP for portfolio selection. This formulation aggregated simultaneously three dimensions, namely: (a) dividends, (b) the growth of earnings; and (c) 50\% dividend payout ratio. Lee and Lerro (1973) have extended Lee (1972) formulation for mutual funds and they concluded that their model allowed to obtain quite similar solutions to those resulting from Markowitz (1952, 1959) and Sharpe (1967) models. Kumar et al. (1978) applied the LGP for dual-purpose funds managed by an investment company issuing two types of shares: (a) income shares and (b) capital shares. In fact, the LGP has been widely applied in financial portfolio selection since the 1980s.

Incorporating skewness into the decision-making process in the context of portfolio selection may cause major change in composition of the financial portfolio comparatively to portfolio based only on the mean-variance model. The PGP model proposed by Lai (1991) allowed incorporating preferences regarding skewness and other objectives and he claimed that this model was more efficient than LGP model. In their paper, Canela and Collazo (2007) have reformulated the different PGP models proposed by Lai (1991), Chunhachinda et al. (1997), (Prakash et al. 2003) and Sun and Yan (2003) and claimed that these formulations may lead to unfeasible solutions.

Several financial decision-making contexts are characterized by uncertainty in which the decision-making parameters are random variables. The SGP model considers goals as stochastic values with a specific probability distribution. Our literature review reveals that several SGP formulations have been proposed for financial portfolio selection by using the notion of deterministic equivalent formulation. However, Aouni and La Torre (2010) introduced the concept of scenario generation in formulating a SGP model applied to portfolio selection. Through this model, probabilities were associated with all possible events or scenarios and the corresponding goals depended on the specific scenario based on the state of nature.

The FGP model was developed to deal with some financial decisional context in which the FDM can only provide vague or imprecise goal values (Arenas-Parra et al. 2001). The FGP is based on the concept of membership function that was introduced by Zimmerman (1976, 1978, 1983) and Freeling (1980) for modeling the fuzziness related to the decision-making parameters. In their paper, Bilbao et al. (2006) provided a formulation based on Sharpe (1967) model by considering ambiguous and vague parameters and calculating the betas using past observations. Their model was applied to Spanish mutual funds. Moreover, Mansour et al. (2007) formulated an imprecise GP model for portfolio selection based on the satisfaction function where the FDM preferences are explicitly incorporated into the decisionmaking process. Their model has been applied to Tunisian stock exchange market.

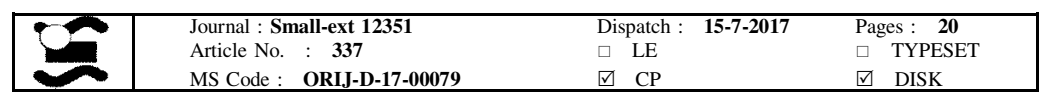


The goals associated with the rate of return, the liquidity and the risk were considered to be imprecise and expressed through an interval-value function.

Several other GP variants have been applied to portfolio management over the years. We can mention: the min-max GP variant (Deng et al. 2005), the interactive GP model (Spronk 1980; Perez et al. 2007), the nonlinear GP model (Li and Xu 2007), the integer GP (Harrington and Fisher 1980) or the mixed-integer GP model (Aouni et al. 2013) and its variants such as the mixed-integer stochastic GP in Stoyan and Kwon (2011).

Recently, the Compromised Programming (CP) model was applied to portfolio selection problem by Ballestero and Romero (1996) and Ballestero (1998). Further extensions include a Fuzzy Compromised GP model (Ballestero et al. 2007) where the distance between fuzzy ideal goal values and the achievement levels were to be minimized. Nowadays, the Chance Constrained Compromise Programming (CCCP) model for the portfolio selection problem (Boswarva and Aouni 2012) is quite popular as well. We remind that the CCCP and the SGP formulations are based on the assumption that aspiration levels of objectives are normally distributed with known mean and variance.

When the FDM implements a GP model, he/she is not passive and his/her preferences and opinions can be taken into consideration in the portfolio selection process. In particular, the concept of satisfaction function developed by Martel and Aouni (1990) has been utilized to explicitly incorporate the FDM preferences. In general, satisfaction functions are taking values in the interval $[0,1]$. Therefore, the satisfaction function gives a value of 1 when the FDM is totally satisfied with the proposed solution. Otherwise, they are monotonically decreasing according to his/ her appreciation of the achievement level of each objective.

Finally, GP formulations are often combined with other methods and techniques to solve multiple criteria problems: the most used are the Analytic Network Process (ANP); the Decision-Making Trial and Evaluation Laboratory (DEMATEL) method; and the Technique for Order of Preference by Similarity to Ideal Solution (TOPSIS).

\section{Data collection}

For the purpose of this paper we extended the dataset of a previous survey produced by Aouni et al. (2014) and deepened the analysis. The most important step in our literature retrieval process was a computer search of Web of Science and Scopus databases. Our search period was not temporally limited. Using the descriptors "Goal Programming", "Financial Portfolio" and "Portfolio Management", we retrieved approximately 21 (Web of science) and 136 (Scopus) abstracts to be added to the 91 papers of our previous research for review. Our initial dataset accounted for 248 papers.

Then we cleaned the database by removing duplicate rows/works. Each publication was carefully reviewed before taking a decision on its inclusion in this study. We excluded survey papers like Azmi and Tamiz (2010) or works that did not deal with financial portfolio management. A final total of 151 outputs (see

\begin{tabular}{|c|c|c|c|}
\hline & $\begin{array}{l}\text { Journal : Small-ext 12351 } \\
\text { Article No. : } \quad 337 \\
\text { MS Code : } \\
\text { ORIJ-D-17-00079 }\end{array}$ & $\begin{array}{l}\text { Dispatch : } \mathbf{1 5 - 7 - 2 0 1 7} \\
\square \quad \text { LE } \\
\nabla \quad \mathrm{CP} \\
\square \quad\end{array}$ & $\begin{array}{l}\text { Pages : } \mathbf{2 0} \\
\square \quad \text { TYPESET } \\
\square \quad \text { DISK } \\
\end{array}$ \\
\hline
\end{tabular}


Appendix) was considered to be acceptable for the purposes of this survey. In particular, we identified: 131 papers (87\%), 3 books (2\%), 5 book chapters (3\%), 10 conference papers (7\%) and 2 working papers (1\%). We classified each output according to the following categories: (a) Year of publication, (b) Journal, (c) Journal area, (d) Country/institution affiliation of the author, (e) Application area, (f) GP variants, and (g) Decision type.

Obviously, most of the data were available on Scopus and Web of Science. The journal area was identified according to the journal citation report. The application area was mainly identified through keywords provided by the authors themselves. For each paper we indicated the country/countries and whether this country belonged to the Organization for Economic Co-operation and Development (OECD), as a proxy for being a developed country. The institution affiliation of the author(s) was also used to describe the kind of collaboration: we were interested to identify if the output was due to an academic collaboration or a bridge collaboration with industry practitioners or governmental officials.

Finally, we were able to distinguish among three different families of 257 information, namely: (a) deterministic, (b) stochastic and (c) fuzzy or imprecise.

258 The remaining categories are self-explanatory.

\section{Bibliographical analysis}

This section summarizes the results and discusses the findings for each of our classified categories. As shown in Fig. 1, there is an increasing interest on the application of the GP model to financial portfolio selection. We notice ten publications in the 1970s, forty-nine papers during 2000s and fifty-eight

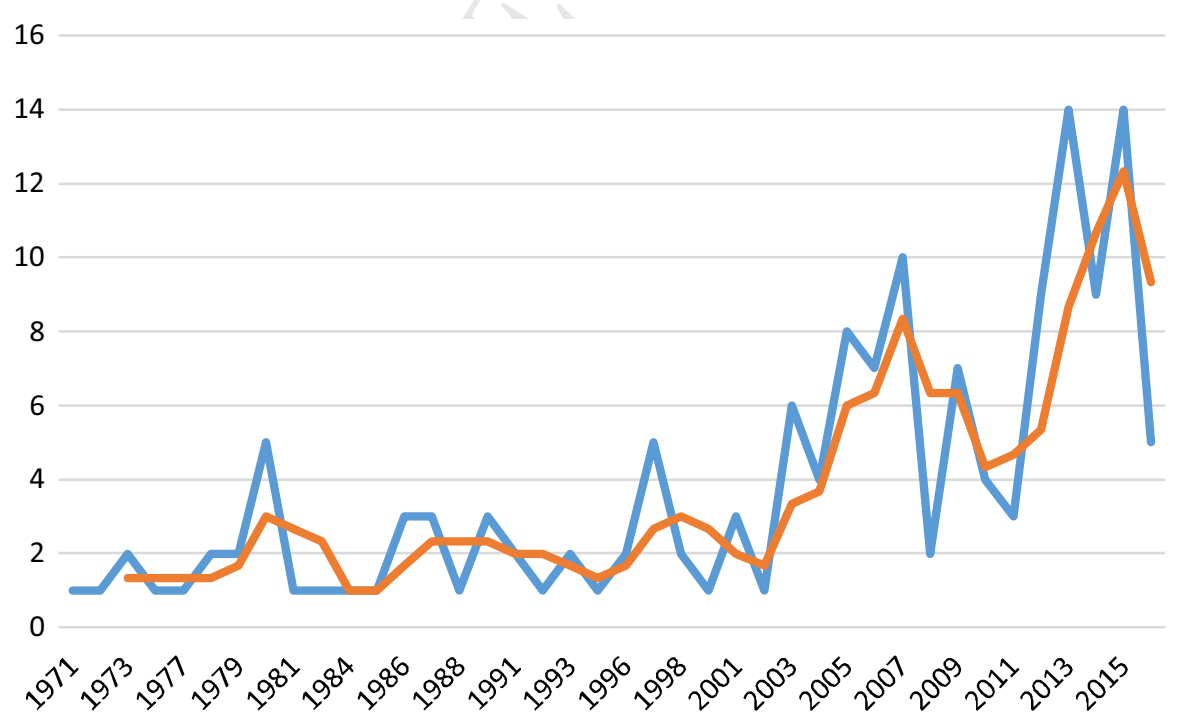

Fig. 1 Time evolution of the publications

Springer

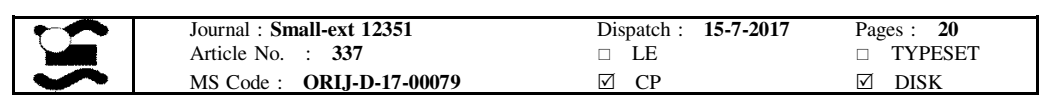


publications during 2010s. The establishment of international conferences (e.g. MOPGP $^{1}$ conferences) might have impacted on this positive trend. The number of papers published in each year ranges from 1 to 14 (with an average equal to 3.8). Due to the possible time lag in reviewing and revising the submitted manuscripts and the scheduling of journal publications, it is justifiable to look at a three-year simple moving average for the publications (red line of Fig. 1). As expected, the values of the moving averages clearly confirm a steadily increasing trend.

Figure 2 summarizes the number of papers, related to financial portfolio selection through the GP model, by country. There are a total of 225 researchers affiliated with different institutions in 36 countries across the world. They have written an average of 1.7 output thus it is a fragmented production. However, we can identify some top authors, namely A. Bilbao Terol (13), B. Aouni (12), M. Arenas Parra (10) and F. Ben Abdelaziz (10). The largest number of authors are affiliated with an American university (22.6\%), followed by affiliations with Spanish (12.4\%), Canadian (6.5\%), Tunisian (4.8\%) and British universities (4.8\%). Together, these five countries (CR5) account for $51.1 \%$, the community is slightly concentrate. There are some considerations to be done in relation to authors' affiliation: during their academic life researchers change universities and countries, in other words the same author can contribute to different 'national' productions. Moreover, a researcher can have a double affiliation and this affects the final results, and makes impossible to provide an accurate measure of the contribution of a single author/country.

Grouping the publications related to the application of the GP model to financial portfolio selection by continent, we found that Europe (29.8\%) is the most productive continent, followed by North America (23.8\%), Asia (22.5\%), Africa $(3.3 \%)$ and Oceania $(0.7 \%)$. Our literature review revealed that there are also several intercontinental collaborations (19.9\%).

Most papers have been written by more than one author $(88.1 \%)$ and the average number of authors per paper is 2.49. As regards the degree of development of a country, we distinguished between works written by authors affiliated with an institution in a developed (OECD members) or developing countries with a dummy variable that takes value 2 when all authors work in an institution of an OECD country or a set of OECD countries (but not one or more developing countries), 1 if at least one of the authors works an institution of an OECD country and 0 otherwise. 96 of the works (63.6\%) are from the 21 developed countries, and $35(23.2 \%)$ are from the 15 developing countries. Our review indicates that, 20 of the 151 research paper (13.2\%) are collaborations between authors from OECD and non-OECD countries. It is clear the predominant role played by Institutions host in developed countries.

With regard to the type of affiliated institution, most of the papers (135 or 89.4\%) were written by university professors and researchers from 129 different universities, 2 (1.4\%) were authored by industry practitioners and government officials, and $14(9.3 \%)$ were jointly written by authors from both sectors. The top universities in terms of output are the University of Oviedo (13 papers), followed by Laurentian University (10 papers), Technical University of Madrid, University of Milan, University of Rhode Island, and University of Tunis (6 papers each). These

\footnotetext{
1 The first MOPGP conference was held at the University of Portsmouth, United Kingdom, June, 1994.
}

Springer

\begin{tabular}{|c|c|c|c|}
\hline & $\begin{array}{l}\text { Journal : Small-ext 12351 } \\
\text { Article No. : } \quad 337 \\
\text { MS Code : } \\
\text { ORIJ-D-17-00079 }\end{array}$ & $\begin{array}{l}\text { Dispatch : } \mathbf{1 5 - 7 - 2 0 1 7} \\
\square \quad \text { LE } \\
\nabla \quad \mathrm{CP} \\
\square \quad\end{array}$ & $\begin{array}{l}\text { Pages : } \mathbf{2 0} \\
\square \quad \text { TYPESET } \\
\square \quad \text { DISK } \\
\end{array}$ \\
\hline
\end{tabular}




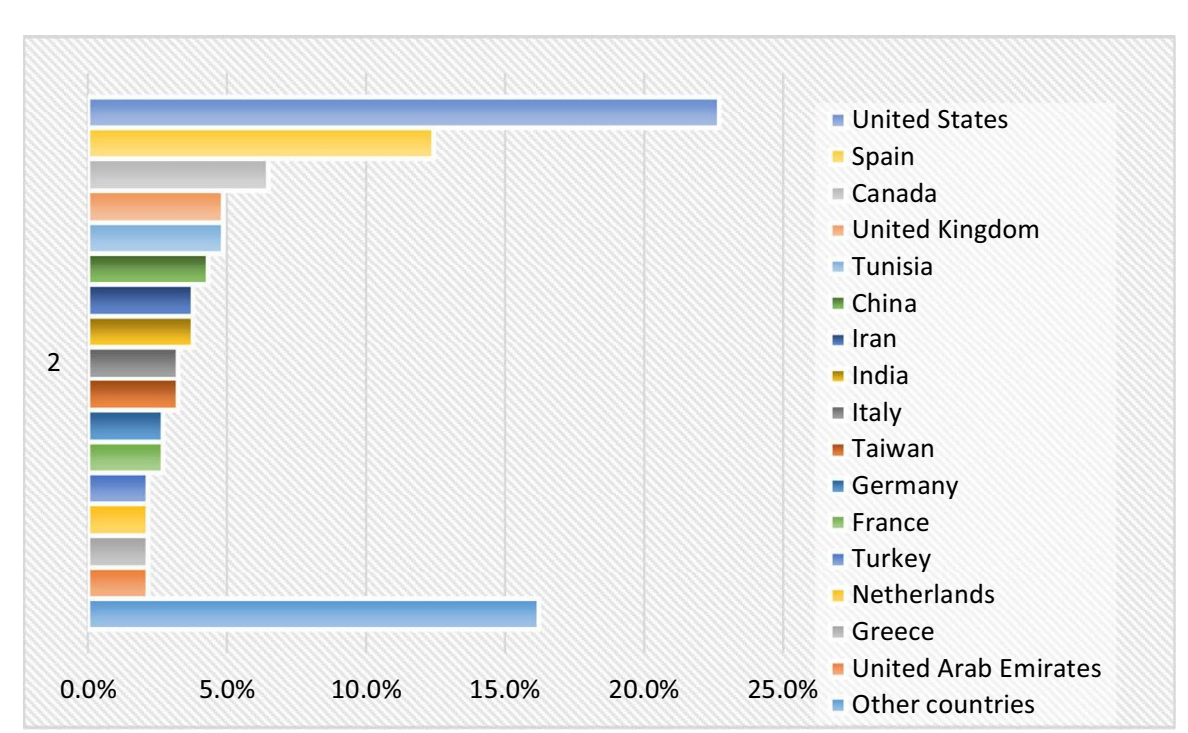

Fig. 2 Distribution by country

data confirm the key role played by European universities in this community and reflect the location of the top authors.

Moving to technical issues related to different GP variants, we noticed that the majority of papers using GP model for portfolio selection and portfolio management are using other variants of GP rather than its standard formulation. Moreover, 31.6\% of the papers are using nonlinear GP, interactive GP and CP. Since 2000, fuzzy techniques are getting more and more popular and they account for $17.4 \%$ of the papers, whilst SGP is the most recent but the less used model (7.7\%) in financial portfolio selection. The WGP variant is still quite popular $(18.1 \%)$ over the years. LGP (11.0\%) and PGP (14.2\%) have been used in a limited manner over the decades. Table 2 shows the most commonly used models for each application area. These categories were developed in response to the papers that we found. The first categories refer to the specific type of securities (e.g. Bank portfolio, Dual-Purpose Funds or SRI). The other categories refer to the different aspects of investment decision (investment analysis, portfolio formation and portfolio management) or to the employed mathematical technique (mathematical modeling or optimization).

A wide variety of techniques are utilized in all different areas. Most works deal with portfolio selection and portfolio management, and the more innovative models are concentrated in these two area. A recent area of application concerns socially responsible investment (SRI): in recent years, sustainable development and social responsibility have become important issues around the globe, thus investment

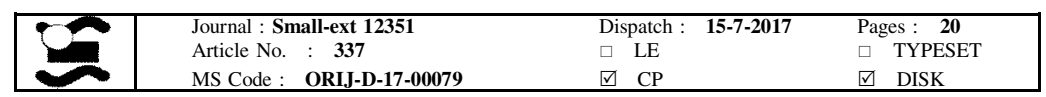




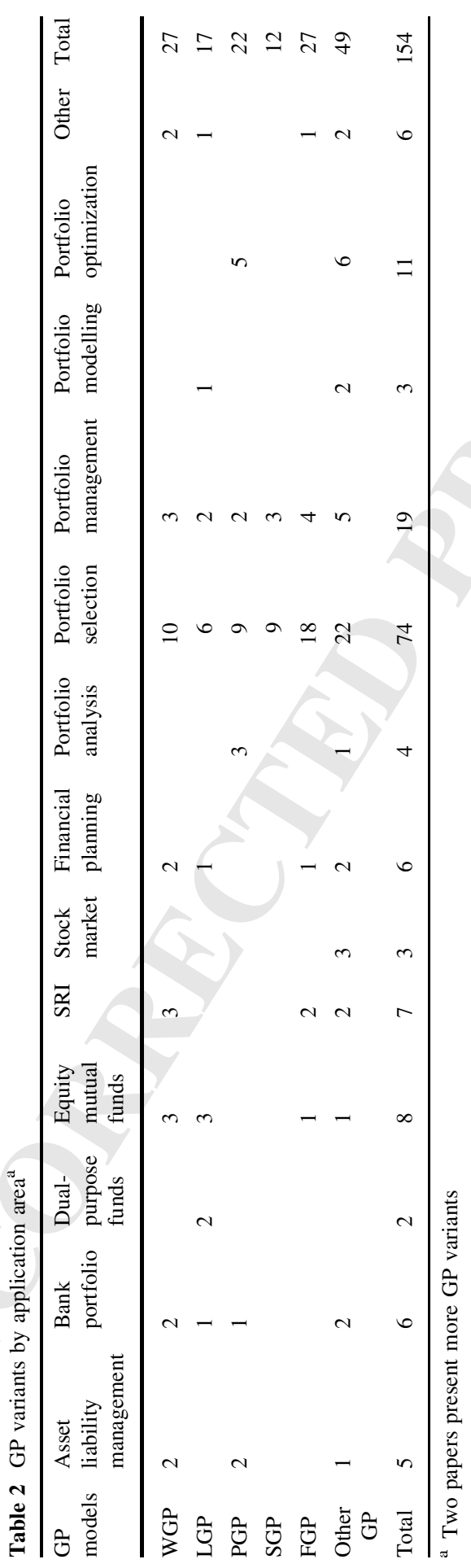

\begin{tabular}{|l|lll|}
\hline & Journal : Small-ext 12351 & Dispatch : 15-7-2017 & Pages : 20 \\
Article No. $: \quad 337$ & $\square$ & LE & TYPESET \\
MS Code : ORIJ-D-17-00079 & $\square$ & CP & $\square$ DISK \\
\hline
\end{tabular}


strategy employs criteria (based on social, environmental and ethical screens ${ }^{2}$ ) other than financial risk and return when selecting firms in which to invest.

Another interesting aspect to explore is about the area and the journals publishing papers related to the application of GP to portfolio selection that may help to better understand the GP community active in this research field. The top journals are in the Operation Research area, namely: European Journal of Operational Research (11.5\%), INFOR (6.9\%), Journal of the Operational Research Society (4.6\%), and Annals of Operations Research (3.8\%). It seems that operational researchers tend to publish their results in OR journals rather than address specialized journals in Finance or Management. We also have some management journals, such as Decision Sciences, Journal of Banking and Finance, and Omega (3.8\% each). All application areas are represented in the journals (Table 3).

Table 4 shows the classification of GP variants based on the type of information related to the parameters of the decision-making situation. We noticed that the GP model is largely applied in deterministic contexts. More recently, we count some applications related to stochastic and fuzzy decision-making contexts.

\section{Concluding remarks}

The aim of this paper is to provide a categorization of the applications of different GP variants for financial portfolio selection and portfolio management according to different characteristics (ranging from the type of information related to the decision-making situation to the application area or the demographic variables across the last decades). The performed literature review shows that the number of papers related to this subject has increased steadily especially over the past two decades, and this trend is expected to continue as the applicability of GP technique in financial portfolio management is fully recognized by researchers worldwide, with a focus in the European area, and in the developed countries in general. With regard to publication outlets, it seems that over the years most academicians have preferred to publish in top journals in operation research. This is due to an increasing use of more sophisticated models (SGP and FGP models) able to provide a more complete representation of complexity, or at least a more complete understanding of the real world (see Table 4).

We also notice that researchers within the field of Management Science and Operations Research are very active in applying the GP model to portfolio selection that was traditionally related to the field of Finance. The rapid increase in using GP model can be explained by the fact that it is an easy tool to be understood and implemented, and it is supported by commercial optimization software. Moreover, the GP model is more flexible than the other MCDA techniques. It is a learning process in which the FDM can interact and continuously adjust the parameters in order to improve the decision-making process through a progressive and evolving

\footnotetext{
2 The environment concern includes climate change and clean technologies or pollution. Under the social concerns we can look at human rights and labor relations for instance. Ethical or governance concerns relate to board issues. Popular negative screens refer to the sin screens (production of alcohol, tobacco or gambling products) or military weapons, just to mention a few.
}

\section{Springer}

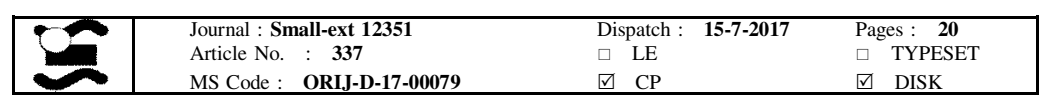


Goal programming for financial portfolio management: a...

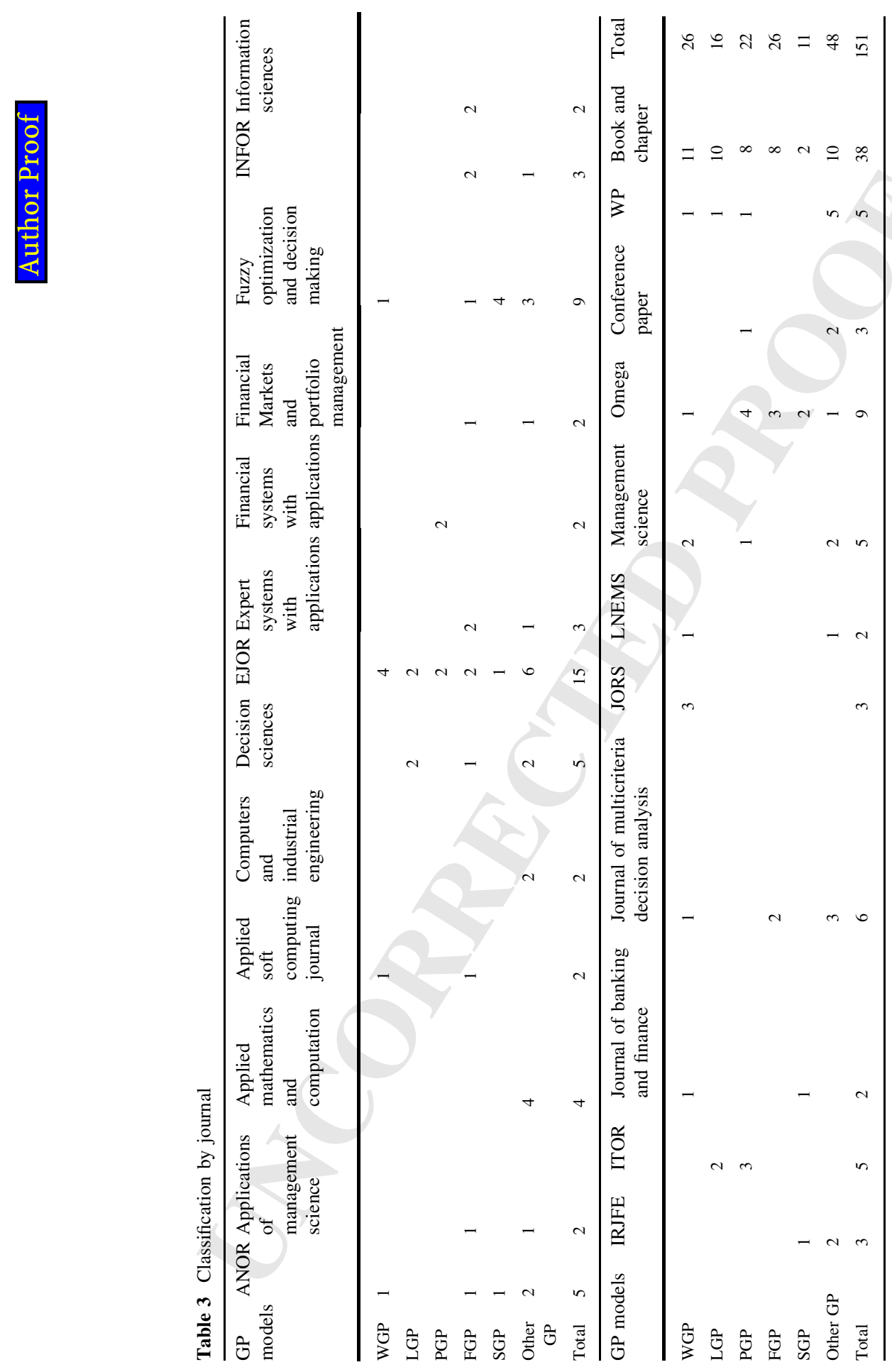

Springer

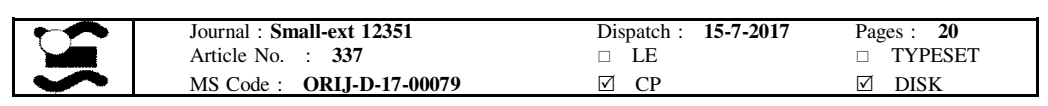


C. Colapinto et al.

Table 4 Information type and GP model in portfolio management $t^{\mathrm{a}}$

\begin{tabular}{llrrrrrr}
\hline $\begin{array}{l}\text { Table } 4 \text { Information type and } \\
\text { GP model in portfolio } \\
\text { management }\end{array}$ & & $1970 \mathrm{~s}$ & $1980 \mathrm{~s}$ & $1990 \mathrm{~s}$ & $2000 \mathrm{~s}$ & $2010 \mathrm{~s}$ & Total \\
\cline { 2 - 8 } & Deterministic & 10 & 17 & 12 & 27 & 26 & 92 \\
& WGP & 2 & 5 & 5 & 6 & 8 & 26 \\
& LGP & 6 & 5 & 1 & 1 & 4 & 17 \\
& PGP & & 1 & 3 & 11 & 7 & 22 \\
& Other GP & 2 & 6 & 3 & 9 & 7 & 27 \\
& Fuzzy & & 1 & 1 & 12 & 20 & 34 \\
& WGP & & & & & 2 & 2 \\
& FGP & & 1 & 1 & 8 & 16 & 26 \\
& Other GP & & & & 4 & 2 & 6 \\
& Stochastic & & 1 & 2 & 13 & 16 & 29 \\
& FGP & & & & & 1 & 1 \\
& SGP & & & & 4 & 8 & 11 \\
& Other GP & & 1 & 2 & 6 & 7 & 16 \\
Trand total & 10 & 19 & 15 & 49 & 62 & 155 \\
\hline variants & & & & & & &
\end{tabular}

${ }^{a}$ Two papers present more GP variants

sequence of actions. The investment decisions are taken by the FDM and the GP model is a tool to support and not to replace humans' decisions. The GP model allows the FDM to express his/her preferences based on his/her intuition, experience and knowledge. In addition, the behavior of the financial portfolio management depends on several external factors that are difficult to control and to predict during the modeling process. These factors are related to: (a) international economy; (b) national economy; (c) international political stability; (d) natural phenomena; and (e) the FDM psychology. Future avenues in GP theory and modeling include the formulation of more complex GP variants that will also try to model the effect of external factors as well as the subjectivity nature of the financial decision making process. In this perspective a more intense collaboration between academic 37 AQ3 researchers and industry practitioners will be beneficial.

\section{Appendix}

\begin{tabular}{llr}
\hline Authors & Journal & Year \\
\hline Aboul-Enein S., Dionne G., Papageorgiou N. & European Journal of Finance & 2013 \\
Alexander G.J., Resnick B.G. & Journal of Banking and Finance & 1985 \\
Allen, J., Bhattacharya, S., Smarandache, F. & International Journal of Social Economics & 2003 \\
Amiri, M., Ekhtiari, M., Yazdani, M. & Expert Systems with Applications & 2011 \\
Aouni B., Colapinto C., La Torre D. & Annals of Operations Research & 2013 \\
Aouni, A., Ben Abdelaziz, F., La Torre, D. & Journal of Multi-Criteria Decision Analysis & 2012 \\
Aouni, A., Colapinto, C., La Torre, D. & Journal of Financial Decision Making & 2010 \\
\hline
\end{tabular}

\begin{tabular}{|c|c|c|c|}
\hline & $\begin{array}{l}\text { Journal : Small-ext 12351 } \\
\text { Article No. : } \quad 337 \\
\text { MS Code : } \\
\text { ORIJ-D-17-00079 }\end{array}$ & $\begin{array}{l}\text { Dispatch : } \mathbf{1 5 - 7 - 2 0 1 7} \\
\square \quad \text { LE } \\
\nabla \quad \mathrm{CP} \\
\square \quad\end{array}$ & $\begin{array}{l}\text { Pages : } \mathbf{2 0} \\
\square \quad \text { TYPESET } \\
\square \quad \text { DISK } \\
\end{array}$ \\
\hline
\end{tabular}


Goal programming for financial portfolio management: a...

\begin{tabular}{|c|c|c|}
\hline Authors & Journal & Year \\
\hline $\begin{array}{l}\text { Aouni, B., Ben Abdelaziz, F, El Fayedh, } \\
\text { R. }\end{array}$ & $\begin{array}{l}\text { Administrative Sciences Association of Canada, } \\
\text { Management Science }\end{array}$ & 2003 \\
\hline $\begin{array}{l}\text { Aouni, B., Ben Abdelaziz, F., Martel, J. } \\
\text { M. }\end{array}$ & European Journal of Operational Research & 2005 \\
\hline Aouni, B., Colapinto, C., La Torre, D. & INFOR & 2014 \\
\hline $\begin{array}{l}\text { Arenas Parra M., Bilbao Terol A., } \\
\text { Rodríguez Uría M.V. }\end{array}$ & European Journal of Operational Research & 2001 \\
\hline Arenas-Parra, M., et al. & Applied Mathematics and Computation & 2006 \\
\hline Bahloul, S. Abid, F. & $\begin{array}{l}\text { International Journal of Multi-Criteria Decision } \\
\text { Making }\end{array}$ & 2013 \\
\hline Ballestero, E. & Journal of Operational Research Society & 1998 \\
\hline Ballestero, E., Pla-Santamaria, D. & International Transactions in Operational Research & 2003 \\
\hline Ballestero, E., Pla-Santamaria, D. & Omega & 2004 \\
\hline Ballestero, E., Romero, C. & Journal of the Operational Research Society & 1996 \\
\hline Ballestero E., Garcia-Bernabeu A. & INFOR & 2012 \\
\hline $\begin{array}{l}\text { Ballestero E., Garcia-Bernabeu A., Hilario } \\
\text { A. }\end{array}$ & Book Chapter & 2015 \\
\hline Ballestero, E., et al. & European Journal of Operational Research & 2007 \\
\hline Ballestero, E., et al. & INFOR & 2009 \\
\hline Batson, R.G. & Long Range Planning & 1989 \\
\hline Ben Abdelaziz F., El Fayedh R., Rao A. & INFOR & 2009 \\
\hline Ben Abdelaziz F., Aouni B., Fayedh R.E. & European Journal of Operational Research & 2007 \\
\hline Ben Abdelaziz F., Masmoudi M. & International Transactions in Operational Research & 2014 \\
\hline $\begin{array}{l}\text { Ben Abdelaziz, F., Aouni, B., El Fayedh, } \\
\text { R. }\end{array}$ & European Journal of Operational Research & 2007 \\
\hline Bilbao A., et al. & Journal of the Operational Research Society & 2006 \\
\hline Bilbao A., et al. & European Journal of Operational Research & 2007 \\
\hline $\begin{array}{l}\text { Bilbao-Terol A., Arenas-Parra M., Cañal- } \\
\text { Fernández V. }\end{array}$ & Expert Systems with Applications & 2012 \\
\hline $\begin{array}{l}\text { Bilbao-Terol A., Arenas-Parra M., Cañal- } \\
\text { Fernández V. }\end{array}$ & Information Sciences & 2012 \\
\hline $\begin{array}{l}\text { Bilbao-Terol A., Arenas-Parra M., Cañal- } \\
\text { Fernández V. }\end{array}$ & Revista de Contabilidad & 2016 \\
\hline Bilbao-Terol A., et al. & Annals of Operations Research & 2015 \\
\hline Bilbao-Terol, A., et al. & Applied Mathematics and Computation & 2006 \\
\hline $\begin{array}{l}\text { Bilbao-Terol, A., Pérez Gladish, B., } \\
\text { Antomil-Ibias, J. }\end{array}$ & Applied Mathematics and Computation & 2006 \\
\hline Booth, G.G., Bessler, W. & Omega & 1989 \\
\hline Booth G.G., Dash Jr. G.H. & Financial Review & 1977 \\
\hline Booth G.G., Dash Jr. G.H. & Journal of Banking and Finance & 1979 \\
\hline Bornman J.J., Smit E.V.M., Gevers W.R. & Investment Analysts Journal & 1993 \\
\hline Boswarva, I. Aouni, B. & INFOR & 2012 \\
\hline $\begin{array}{l}\text { Bravo, M., Pla Santamaria, D., Garcia- } \\
\text { Bernabeu, A. }\end{array}$ & Journal of Multi-criteria Decision Analysis & 2010 \\
\hline
\end{tabular}

\begin{tabular}{|c|c|c|c|}
\hline & $\begin{array}{l}\text { Journal : Small-ext 12351 } \\
\text { Article No. }: \quad 337 \\
\text { MS Code : } \\
\text { ORIJ-D-17-00079 }\end{array}$ & $\begin{array}{l}\text { Dispatch： } \mathbf{1 5 - 7 - 2 0 1 7} \\
\square \quad \text { LE } \\
\square \quad \mathrm{CP}\end{array}$ & $\begin{array}{l}\text { Pages : } \mathbf{2 0} \\
\square \quad \text { TYPESET } \\
\square \quad \text { DISK }\end{array}$ \\
\hline
\end{tabular}




\begin{tabular}{|c|c|c|}
\hline Authors & Journal & Year \\
\hline $\begin{array}{l}\text { Briec W., Kerstens K., Van De } \\
\text { Woestyne I. }\end{array}$ & European Journal of Operational Research & 2013 \\
\hline Callahan, J. & Cost and Management & 1973 \\
\hline Canela M.Á., Collazo E.P. & Emerging Markets Review & 2007 \\
\hline Chang, C.-T. & Applied Mathematics and Computation & 2005 \\
\hline Chen, H.-H. & Review of Pacific Basin Financial Markets and Policies & 2008 \\
\hline Chunhachinda P., et al. & Journal of Banking and Finance & 1997 \\
\hline Colapinto, C., La Torre, D. & conference paper & 2015 \\
\hline Colson G., De Bruyn C. & Mathematical and Computer Modelling & 1989 \\
\hline Cooper W.W., Lelas V., Sueyoshi T. & European Journal of Operational Research & 1997 \\
\hline Dash G.H., Jr., Kajiji N. & Book Chapter & 2014 \\
\hline Dash G.H., Jr., Kajiji N. & International Transactions in Operational Research & 2014 \\
\hline Dash G.H., Jr., Kajiji N. & INFOR & 2005 \\
\hline Davies R.J., Kat H.M., Lu S. & Journal of Derivatives and Hedge Funds & 2009 \\
\hline Deng, X.-T., Li, Z.-F., Wang, S.-Y. & European Journal of Operational Research & 2005 \\
\hline Dominiak, $\mathrm{C}$. & Book Chapter & 1997 \\
\hline Ekhtiari, M., Alinezhad, A. & $\begin{array}{l}\text { Economic Computation and Economic Cybernetics } \\
\text { Studies and Research }\end{array}$ & 2015 \\
\hline Elkaim A., Papageorgiou N. & Book Chapter & 2006 \\
\hline García-Bernabeu A., et al. & Economia Agraria y Recursos Naturales & 2015 \\
\hline Ghahtarani A., Najafi A.A. & Economic Modelling & 2013 \\
\hline Gupta, P., Bhattacharjee, D. & $\begin{array}{l}\text { International Research Journal of Finance and } \\
\text { Economics }\end{array}$ & 2010 \\
\hline Gupta P., Mittal G., Mehlawat M.K. & Insurance: Mathematics and Economics & 2013 \\
\hline Gupta P., Mittal G., Mehlawat M.K. & Optimization Letters & 2013 \\
\hline Hafner R., Wallmeier M. & Financial Markets and Portfolio Management & 2008 \\
\hline Hallerbach, W.G., Spronk, J. & $W P$ & 1986 \\
\hline Harrington, T.C., Fisher, W. & Decision Sciences & 1980 \\
\hline He F., Qu R., John R. & conference paper & 2015 \\
\hline Hitaj A., Zambruno G. & Review of Financial Economics & 2016 \\
\hline Hossain S.A., Bhattacharyya F & conference paper & 2015 \\
\hline Ignizio, P.J. & Decision Sciences & 1982 \\
\hline Inuiguchi, M., Ramik, J. & Fuzzy Sets and Systems & 2000 \\
\hline Jaaman S.H., Lam W.H., Isa Z. & International Journal of Operational Research & 2014 \\
\hline Ji X., et al. & IIE Transactions (Institute of Industrial Engineers) & 2005 \\
\hline Jobst, N. et al. & Quantitative Finance & 2001 \\
\hline Kaminski B., Czupryna M., Szapiro T. & Lecture Notes in Economics and Mathematical Systems & 2009 \\
\hline Keskin R., Kocadatli O., Cinemre N. & Journal of Intelligent and Fuzzy Systems & 2015 \\
\hline $\begin{array}{l}\text { Khalili-Damghani K., Sadi-Nezhad S., } \\
\text { Tavana M. }\end{array}$ & Information Sciences & 2013 \\
\hline Kocadatli O., Keskin R. & Expert Systems with Applications & 2015 \\
\hline Konno, H., Yamazaki, H. & Management Science & 1991 \\
\hline Korhonen, A. & European Journal of Operational Research & 1987 \\
\hline
\end{tabular}

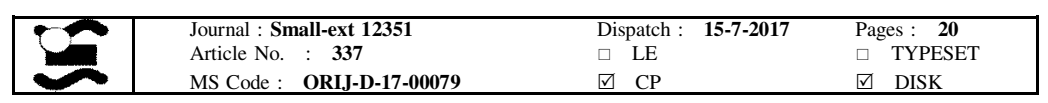


Goal programming for financial portfolio management: a...

\begin{tabular}{|c|c|c|}
\hline Authors & Journal & Year \\
\hline Kornbluth J.S.H., Salkin G.R. & Omega & 1992 \\
\hline Kornbluth J.S.H., Salkin G.R. & Journal of the Operational Research Society & 1993 \\
\hline Kosmidou, K. Zopounidis, C. & INFOR & 2004 \\
\hline $\begin{array}{l}\text { Kumar, P.C., Philippatos, G.C., } \\
\text { Ezzell, J.R. }\end{array}$ & Journal of Finance & 1978 \\
\hline Kumar, P. C., Philippatos, G. C. & Decision Sciences & 1979 \\
\hline Kvanli, A. H. & Omega & 1980 \\
\hline Lai K.K., Yu L., Wang S. & conference paper & 2006 \\
\hline Lai, T. Y & Review of Quantitative Finance and Accounting & 1991 \\
\hline Lam, W.H., Jaaman, S.H.H., Isa, Z. & conference paper & 2013 \\
\hline Lawrence, K.D., et al. & Applications of Management Science & 2009 \\
\hline $\begin{array}{l}\text { Lawrence, K.D., Pai D.R., } \\
\text { Lawrence, S.M. }\end{array}$ & Applications of Management Science & 2015 \\
\hline Lee, S. M. & Book & 1972 \\
\hline Lee, S.M., Chesser, D.L. & The Journal of Portfolio Management & 1980 \\
\hline Lee, S. M., Lerro, A. J. & Journal of Finance & 1973 \\
\hline Lee, S. M., Sevebeck, W. R. & Policy Sciences & 1971 \\
\hline $\begin{array}{l}\text { Leung, M.T., Daouk, H., Chen, A.- } \\
\text { S. }\end{array}$ & European Journal of Operational Research & 2001 \\
\hline Levary, R. R., Avery, M. L. & Operation Research & 1984 \\
\hline Li, J., Xu, J. & Fuzzy Optimization and Decision Making & 2007 \\
\hline Lin, C.-C., Liu, Y.-T., Chen, A.-P. & Applied Soft Computing Journal & 2016 \\
\hline Liu, Y.-J., Zhang, W.-G., Xu, W.-J. & $\begin{array}{l}\text { Xitong Gongcheng Lilun yu Shijian/System Engineering } \\
\text { Theory and Practice }\end{array}$ & 2013 \\
\hline Lucey, B., Tully, E., Poti, V. & $W P$ & 2004 \\
\hline Maggis, M., La Torre, D. & INFOR & 2012 \\
\hline Mansour, N., Rebaï, A., Aouni, B. & Journal of Industrial Engineering International & 2007 \\
\hline Masmoudim, M., Ben Abdelazi & Annals of Operations Research & 2015 \\
\hline Masmoudim, M., Ben Abdelaziz, F. & INFOR & 2012 \\
\hline Masri, H. & Annals of Operations Research & 2015 \\
\hline Mehlawat, M.K. & Information Sciences & 2016 \\
\hline Messaoudi, L., Aouni, B., Rebai, A. & Annals of Operations Research & 2015 \\
\hline Messaoudi, L., Rebaï, A. & conference paper & 2013 \\
\hline Messaoudi, L., Rebaï, A. & International Journal of Applied Decision Sciences & 2014 \\
\hline $\begin{array}{l}\text { Muhlemann, A. P., Lockett, A. G., } \\
\text { Gear, A. E. }\end{array}$ & Decision Sciences & 1978 \\
\hline Muhlemann, A., Lockett, A. & Decision Sciences & 1980 \\
\hline Ni, H., Wang, Y. & Applied Soft Computing Journal & 2013 \\
\hline O’Leary, J. H., O’Leary, D. E. & Book Chapter & 1987 \\
\hline $\begin{array}{l}\text { Pakdel, A., Noroozzadeh, R., } \\
\text { Sadeghi, P. }\end{array}$ & Australian Journal of Basic and Applied Sciences & 2012 \\
\hline
\end{tabular}

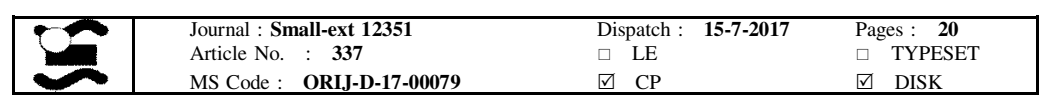




\begin{tabular}{|c|c|c|}
\hline Authors & Journal & Year \\
\hline $\begin{array}{l}\text { Pardalos, P.M., Steponaviče, I., Žilinskas, } \\
\text { A. }\end{array}$ & Optimization Letters & 2012 \\
\hline $\begin{array}{l}\text { Pendaraki, K., Zopounidis, C., Doumpos, } \\
\text { M. }\end{array}$ & European Journal of Operational Research & 2005 \\
\hline $\begin{array}{l}\text { Pendaraki, K., Doumpos, M., Zopounidis, } \\
\text { C. }\end{array}$ & Journal of Asset Management & 2004 \\
\hline Perez Gladish, B., et al. & Omega & 2007 \\
\hline Powell, J.G., Premachandra, I.M. & European Journal of Operational Research & 1998 \\
\hline Prakash, A.J., Chang, C.-H., Pactwa, T.E. & Journal of Banking and Finance & 2003 \\
\hline Proelss, J., Schweizer, D. & Financial Markets and Portfolio Management & 2014 \\
\hline Rimeh, E.F., Ben Abdelaziz, F., Belaid A. & conference paper & 2013 \\
\hline Rostamy, A., Azar, A., Hosseini, S & Finance India & 2003 \\
\hline Sharda, R., Musser, T. & Management Science & 1986 \\
\hline Shariat, N., Ketabi, S. & International Business Management & 2016 \\
\hline Sharma, H.P., Sharma, D.K., Jana, R.K. & $\begin{array}{l}\text { International Research Journal of Finance and } \\
\text { Economics }\end{array}$ & 2009 \\
\hline Sharma, H., Sharma, D & Journal of Business and Economics Research & 2006 \\
\hline Sharma, H., Ghosh, D., Sharma, D. & Academy of Banking Studies & 2007 \\
\hline $\begin{array}{l}\text { Sharma, J. K., Sharma, D. K., Adeyeye, J. } \\
\text { O. }\end{array}$ & Indian Journal of Finance and Research & 1995 \\
\hline Simonian, J. & Applied Economics Letters & 2015 \\
\hline Spronk, J. & Book & 1980 \\
\hline Spronk, J. & Book & 1981 \\
\hline Spronk, J., Wijst, V.D. & $W p$ & 1987 \\
\hline Stone, B. K., Reback, R. & Journal of Bank Research & 1975 \\
\hline Stoyan S.J., Kwon R.H. & Computers and Industrial Engineering & 2011 \\
\hline Sun, Q., Yan, Y. & Journal of Banking and Finance & 2003 \\
\hline Tamiz, M., Azmi, R.A., Jon & European Journal of Operational Research & 2013 \\
\hline Tamiz, M., et al. & $\begin{array}{l}\text { Lecture notes in Economics and Mathematical } \\
\text { Systems }\end{array}$ & 1997 \\
\hline Tamiz, M., et al. & $\begin{array}{l}\text { Lecture Notes in Economics and Mathematical } \\
\text { Systems }\end{array}$ & 1996 \\
\hline Tayi, G. K., Leonard, P. A. & The Journal of the Operational Research Society & 1988 \\
\hline Taylan, A.S., Tatlidil, H. & conference paper & 2010 \\
\hline Tektas, A., Ozkan-Gunay, E., Gunay, G. & Journal of Risk Finance & 2005 \\
\hline Trenado, M., et al. & Computers and Industrial Engineering & 2014 \\
\hline Tsai, W.-H., Chou, W.-C., Hsu, W. & Journal of the Operational Research Society & 2009 \\
\hline Wang, S., Zhu, S. & Fuzzy Optimization and Decision Making & 2002 \\
\hline Watada, J. & Tatra Mountains Mathematical Publications & 1997 \\
\hline Wu, L.-C., Tsai, I.-C. & Journal of the Operational Research Society & 2014 \\
\hline Xu, Q., Jiang, C. and King, P. & conference paper & 2007 \\
\hline Zaloom, V., Tolga, A., Chu, H. & Computers \& Industrial Engineering & 1986 \\
\hline $\begin{array}{l}\text { Zopounidis, C., Doumpos, M., Pendaraki, } \\
\text { K. }\end{array}$ & European Journal of Operational Research & 2005 \\
\hline
\end{tabular}

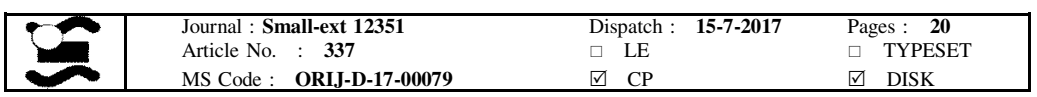




\section{References}

386 Aouni B (2009) Multi-attribute portfolio selection: new perspectives. Inf Syst Oper Res 47(1):1-4

Aouni B (2010) Portfolio selection through the goal programming model: an overview. J Financ Decis Mak 6(2):3-15

389 Aouni A, La Torre D (2010) A generalized stochastic goal programming model. Appl Math Comput
390 215:4347-4357

389 Aouni A, La Torre D (2010) A generalized stochastic goal programming model. Appl Math Comput
$390 \quad 215: 4347-4357$

4 Aouni B, Hassaine A, Martel JM (2009) Decision-maker's preferences modeling within the goal programming model: a new typology. J Multi-Criteria Decis Anal 16:163-178

Aouni A, Colapinto C, La Torre D (2013) A cardinality constrained stochastic goal programming model with satisfaction function for venture capital investment decision making. Ann Oper Res 205(1):77-88

Aouni B, Colapinto C, La Torre D (2014) Financial portfolio management through the goal programming model: current state-of-the-art. Eur J Oper Res 234(2):536-545

Arenas-Parra M, Bilbao-Terol A, Rodriguez Uria MV (2001) A fuzzy goal programming approach to portfolio selection. Eur J Oper Res 133:287-297

Azmi R, Tamiz M (2010) A review of goal programming for portfolio selection. Lect Notes Econ Math Syst 638:15-33

Ballestero E (1998) Approximating the optimum portfolio for an investor with particular preferences. J Oper Res Soc 49:998-1000

Ballestero E, Romero C (1996) Portfolio selection, a compromise programming solution. J Oper Res Soc 47:1377-1386

Ballestero E, Gunther M, Pla-Santamaria D, Stummer C (2007) Portfolio selection under strict uncertainty: a multi-criteria methodology and its application to the Frankfurt and Vienna stock exchange. Eur J Oper Res 181(3):1476-1487

Bilbao-Terol A, Arenas-Parra M, Cañal-Fernández V, Bilbao-Terol C (2015) Multi-criteria decision making for choosing socially responsible investment within a behavioral portfolio theory framework: a new way of investing into a crisis environment. Ann Oper Res. doi:10.1007/ s10479-015-1947-9

Boswarva I, Aouni B (2012) Different probability distributions for portfolio selection in the chance constrained compromise programming model. INFOR 50:140-146

Bravo M, Pla Santamaria D, Garcia-Bernabeu A (2010) Portfolio selection from multiple benchmarks: a goal programming approach to an actual case. J Multicriteria Decis Anal 17:155-166

Canela MA, Collazo EP (2007) Portfolio selection with skewness in emerging market industries. Emerg Mark Rev 8:230-250

Charnes A, Cooper WW (1961) Management models and industrial applications of linear programming. Wiley, New York

Charnes A, Cooper WW, Ferguson RO (1955) Optimal estimation of executive compensation by linear programming. Manag Sci 2:138-151

Chunhachinda P, Dandapani K, Hamid S, Prakash AJ (1997) Portfolio selection and skewness: evidence from international stock markets. J Bank Finance 21:143-167

Deng X-T, Li Z-F, Wang S-Y (2005) A minimax portfolio selection strategy with equilibrium. Eur J Oper Res 166:278-292

Freeling ANS (1980) Fuzzy sets and decision analysis. IEEE Trans Syst 10:341-354

5 Harrington T, Fisher W (1980) Portfolio modeling in multiple criteria situations under uncertainty: comment. Winter: Decis Sci 11:171-177

Kettani O, Aouni B, Martel J-M (2004) The double role of the weight factor in the goal programming model. Comput Oper Res 31:1833-1845

Kumar PC, Philippatos GC, Ezell JR (1978) Goal programming and the selection of portfolios by dual purpose funds. J Finance 33(1):303-310

Lai TY (1991) Portfolio selection with skewness: a multi-objective approach. Rev Quant Finance Account 1(3):293-305

Lee SM (1972) Goal programming for decision analysis. Auerbach, Philadelphia

438 Lee SM, Lerro AJ (1973) Optimizing the portfolio selection for mutual funds. J Finance 28(5):1087-1101

439

Li J, Xu J (2007) A class of possibilistic portfolio selection model with interval coefficients and its application. J Fuzzy Optim Decis Mak Archive 6(2):123-137

\begin{tabular}{|c|c|c|c|}
\hline & $\begin{array}{l}\text { Journal : Small-ext 12351 } \\
\text { Article No. : } \quad 337 \\
\text { MS Code : } \\
\text { ORIJ-D-17-00079 }\end{array}$ & $\begin{array}{l}\text { Dispatch : } \mathbf{1 5 - 7 - 2 0 1 7} \\
\square \quad \text { LE } \\
\nabla \quad \mathrm{CP} \\
\square \quad\end{array}$ & $\begin{array}{l}\text { Pages : } \mathbf{2 0} \\
\square \quad \text { TYPESET } \\
\square \quad \text { DISK } \\
\end{array}$ \\
\hline
\end{tabular}


44 A 441 442

443

Lin TW, O’Leary DE (1993) Goal programming application in financial management. In: Lawrence KD, Guerard JB, Reeves GR (eds) Advances in mathematical programming and financial planning, 3: 211-229. JAI Press Inc, Stamford

Markowitz HM (1952) Portfolio selection. J Finance 7:77-91

Martel JM, Aouni B (1990) Incorporating the decision maker's preferences in the goal programming model. J Oper Res Soc 41:1121-1132

Pendaraki K, Zopounidis C, Doumpos M (2005) On the construction of mutual fund portfolios: a multicriteria methodology and an application to the Greek market of equity mutual fund. Eur J Oper Res 163(2):462-481

Pérez Gladish B, Jones D, Tamiz M, Terol B (2007) An interactive three-stage model for mutual funds portfolio selection. Int J Manag Sci Omega 35:75-88

Prakash AJ, Chang C, Pactwa TE (2003) Selecting a portfolio with skewness: recent evidence from US, European, and Latin American equity markets. J Bank Finance 27:1375-1390

Sharpe WF (1967) A linear programming algorithm for mutual funds portfolio selection. Manag Sci 13(3):499-510

Spronk J (1980) Interactive multiple goal programming for capital budgeting and financial planning. Delftse Uitgevers Maatschappij, Delft

Stoyan SJ, Kwon RH (2011) A stochastic-goal mixed-integer programming approach for integrated stock and bond portfolio optimization. J Comput Indus Eng 61(4):1285-1295

Sun Q, Yan Y (2003) Skewness persistence with optimal portfolio selection. J Bank Finance 27:1111-1121

Zimmerman H-J (1976) Description and optimization of fuzzy systems. Int J Gen Syst 2:209-215

Zimmerman H-J (1978) Fuzzy programming and linear programming with several objectives functions. Fuzzy Sets Syst 1:45-55

Zimmerman H-J (1983) Using fuzzy sets in operations research. Fuzzy Sets Systems 13:201-216

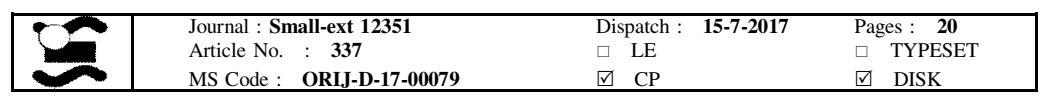

